\title{
Reestruturação produtiva, trabalho e estratégias de desenvolvimento local à luz da teoria do novo regionalismo
}

\section{Productive restructuring, labour and local development strategies based on the New Regionalism Theory}

\author{
Simone de Souza ${ }^{1}$ \\ Antonio Carvalho Neto
}

\section{Resumo}

Este artigo busca contribuir com a discussão sobre a influência do processo de reestruturação produtiva do setor siderúrgico brasileiro na década de 1990 sobre o desenvolvimento local. A agenda das ciências sociais tem discutido os impactos dessa transformação na estrutura produtiva das empresas e no nível de emprego das cidades. Diante desse panorama, o poder local está assumindo uma série de políticas de atração de empresas e atividades econômicas para seus territórios. O enfoque teórico escolhido foi a teoria do novo regionalismo, abordagem de desenvolvimento mais rara na literatura. Este estudo de caso foi realizado na cidade pólo da região do Vale do Aço, leste de Minas Gerais, com o intuito de analisar os impactos da reestruturação produtiva de uma grande corporação industrial siderúrgica no mercado de trabalho local e 0 papel dos stakeholders da cidade em articular coalizões para promover o desenvolvimento. Os resultados analisados reproduzem o que foi encontrado na literatura afim, no que diz respeito à perda de significância do setor industrial em contraposição ao ocorrido nos setores de serviços e de comércio no mercado de trabalho daquela região, bem como o papel dos stakeholders da cidade na articulação de coalizões para promover 0 desenvolvimento local. Também se constatou que a rede de cooperação entre os stakeholders é limitada para estimular o crescimento do município.

Palavras-chave: reestruturação produtiva; mercado de trabalho local; desenvolvimento local; teoria do novo regionalismo; stakeholders locais.

\begin{abstract}
This article aims to discuss the influence of the Brazilian siderurgic sector restructuring during the 1990s on local development. Social Sciences agenda have discussed the influence of these processes on production structures and on local employment level. Facing this challenge, local power is assuming a series of public policies to atract private investment. The theorethical framework is based on the New Regionalism Theory, a relatively rare approach on literature. The research which originated this case study was developed in a region named Steel Valley, Minas Gerais Department, Brazil. It analyses the influence of a siderurgic corporation restructuring on local labour market and local stakeholders role to articulate coalitions to promote development. Results show industrial sector decline in contradiction with services and commerce sectors growing. The cooperation network among local stakeholders is still limited in order to stimulate local economic growing.
\end{abstract}

Keywords: productive restructuring; local labour market; local development; new regionalism theory; local stakeholders.

\footnotetext{
${ }^{1}$ Mestre em Ciências Sociais. Professora do Departamento de Ciências Sociais da Pontifícia Universidade Católica de Minas Gerais - PUC-MG. Endereço: Programa de Pós-Graduação da PUC Minas/FDC,Av. Itaú, no 525 - Dom Cabral - Belo Horizonte - Minas Gerais - Brasil - CEP: 30535-012. E-mail: simoneipatinga@ig.com.br

${ }^{2}$ Doutor em Administração. Professor permanente do Programa de Pós-Graduação em Administração da Pontifícia Universidade Católica de Minas Gerais PPGA/PUC-MG. Endereço: Programa de Pós-Graduação da PUC Minas/FDC. Av. Itaú, no 525 - Dom Cabral - Belo Horizonte - Minas Gerias - Brasil - CEP: 30535-012. E-mail: carvalhoneto@pucminas.br
}

Artigo submetido em outubro de 2007 e aceito em setembro de 2009 


\section{Introdução}

Nas últimas décadas, tem-se discutido sobre as inúmeras transformações mundiais e suas consequiências para as empresas. A reestruturação produtiva acarretada pela globalização da economia e pelo predomínio do ideário liberal trouxe para as organizações maior necessidade de inserção nesse mercado global. Em resposta a essa nova realidade econômica, durante a década de 1990, ocorreram no Brasil mudanças que impactaram o setor siderúrgico. Para sobreviver à abertura de mercado e ao acirramento da competição internacional, esse setor vem investindo significativamente em tecnologia e na produção "enxuta", reformulando seu processo de trabalho e promovendo inovações gerenciais na linha da acumulação flexível. Além de mudanças no mercado de trabalho, constata-se a fragilidade do Estado-nação, não apenas para induzir o desenvolvimento no nível do obtido em décadas anteriores, mas também para conduzir políticas macroeconômicas capazes de patrocinar uma aceleração na geração de emprego e de renda.

Pode-se afirmar que as mudanças em curso decorrentes da reestruturação produtiva estão impactando o nível de desenvolvimento das cidades, colocando difíceis desafios para o poder local organizar e desenvolver uma rede interinstitucional de confiança e cooperação entre os stakeholders ${ }^{1}$ locais, condição primordial para estabelecer uma governança ${ }^{2}$ que possibilita obter êxito nas políticas públicas. O poder local está mudando sua abordagem para o empreendedorismo urbano, caracterizado pelo novo papel influenciado por uma visão mais próxima da lógica empresarial de planejamento estratégico, marketing da cidade, busca do consenso entre os stakeholders locais em torno de projetos hegemônicos e parcerias entre as esferas pública e privada. Isto é, o poder local está assumindo novos compromissos na agenda de geração de emprego e renda, implementando uma série de políticas de atração de empresas e atividades econômicas para seus territórios.

Diante desse cenário complexo de mudanças é que se propõe discutir os impactos da reestruturação produtiva da Usinas Siderúrgicas de Minas (Usiminas) sobre a cidade de Ipatinga. A estrutura urbana da cidade foi construída às pressas em 1958, para abrigar a população envolvida na construção da empresa e também aqueles que passaram a trabalhar na fábrica. Portanto, existe uma relação de identidade indústria/cidade, no qual a empresa teve que assumir o papel do Estado em construir a cidade. Outro aspecto é que a relação de dependência econômica que a urbe tem em relação à Usiminas se mantém muito forte. Partindo dessas premissas, que se confirmaram, o objetivo deste artigo é analisar os impactos da reestruturação produtiva da Usiminas no período 1990-2003 sobre o mercado de trabalho da cidade e o papel dos stakeholders locais na realização de parcerias para conduzir políticas públicas anteriormente atribuídas ao Estado-nação.

Para atender aos propósitos deste estudo de caso foram adotadas duas estratégias de coleta de dados, fugindo da dicotomia pesquisa quantitativa versus pesquisa qualitativa. A primeira estratégia, de caráter qualitativo, contou com pesquisa de campo e análise de documentos fornecidos pela empresa. O trabalho de campo teve como bases, observações in loco e a realização de 20 entrevistas semi-estruturadas com os gestores da prefeitura, com gerentes da Usiminas, dirigentes sindicais e com empresários locais. A segunda estratégia, de caráter quantitativo, consistiu no tratamento de dados secundários sobre o mercado de trabalho da cidade de Ipatinga. Trabalhou-se com dados da Relação Anual de Informações Sociais (Rais) e do Relatório Anual da Usiminas. O objetivo da coleta de dados secundários foi cruzar informações e auxiliar na análise dos resultados dos dados primários.

Como o objetivo do artigo é analisar os impactos da reestruturação produtiva no mercado de trabalho, e essa reestruturação deu-se após a privatização da empresa, ocorrida em 1991, optou-se por circunscrever o período de análise de 1990 a 2003. Focar nesse período permite observar as mudanças ocorridas antes e logo após a privatização, bem como as várias etapas da reestruturação verificada basicamente nos anos 1990. Desde o final daquela década, têm sido constatadas certa estabilidade e ausência de significativas reestruturações. 
O artigo está dividido em quatro seções. A primeira traz uma breve revisão da literatura sobre a reestruturação produtiva; em especial, seus efeitos sobre o setor siderúrgico e também os efeitos sobre o mercado de trabalho. Na segunda seção, o artigo discute os impactos da reestruturação produtiva sobre as cidades, na perspectiva da teoria do novo regionalismo. Na terceira e quarta seções são apresentados os resultados da pesquisa empírica e se procura fazer uma breve reconstrução da história da empresa/cidade. $\mathrm{O}$ intuito é permitir que o leitor compreenda o processo de privatização e a reestruturação produtiva da maior empresa siderúrgica do país, além dos impactos no desenvolvimento e no crescimento econômico de Ipatinga. Também são analisadas as estratégias de desenvolvimento dos stakeholders locais para realizar parcerias e conduzir políticas públicas que anteriormente eram reservadas ao Estado-nação, à luz da teoria do novo regionalismo.

\section{Reestruturação produtiva na indústria siderúrgica e impactos no mercado de trabalho}

O círculo virtuoso que prevaleceu durante a era do fordismo sofreu drástica mudança no final dos anos 1960 , afetando determinados países, regiões, setores da economia e segmentos da sociedade.

A abordagem aqui adotada não tem a pretensão de aprofundar-se nos sintomas desse esgotamento, mas pontuar vários fatores que, segundo Ferreira (1993, p.9), estão articulados entre si, como:

- a queda da produtividade, associada a investimentos cada vez mais altos e a salários elevados que gerava declínio das taxas de lucro;

- a elevação dos preços das matérias primas, especialmente do petróleo;

- a mobilização intensa com greves e manifestações nos locais de trabalho;

- a competição com a Europa e o Japão pelos mercados dos países do Sudeste Asiático e da América Latina.

Diante desse cenário, Antunes (2002, p.120) e Ferreira (1993, p.11) indicam que os países centrais implantaram durante os anos 1970 e 1980, duas tentativas para superar essa situação:

1. a estratégia neoliberal - que propõe a privatização do Estado, a flexibilidade do mercado de trabalho mediante profunda redução nas conquistas obtidas pelos trabalhadores durante a idade de ouro do fordismo, o repúdio aos antigos compromissos sociais (como a indexação dos salários, que estavam condicionados à inflação e à produtividade da empresa), a redução da cobertura e da extensão da previdência social (aliviando a carga sobre o Estado e a empresa), a liberalização dos procedimentos de demissão e a proliferação de empregos precários;

2. a estratégia ofensiva - que propõe reverter a tendência à desaceleração dos ganhos de produtividade, relacionando aumento de produtividade a uma articulação entre reestruturação produtiva e as novas tecnologias (da chamada Terceira Revolução Industrial), incluindo aí, mudanças de caráter organizacional.

No Brasil, constata-se que essa crise não seguiu os rumos da crise clássica do fordismo observados nos países capitalistas desenvolvidos. Para pesquisadores como Antunes (1995, p.98), Druck (1999, p.125) e Ferreira (1993, p.12), as causas da crise estão associadas ao esgotamento da capacidade do Estado manter o padrão de acumulação sustentado no modelo de substituição de importações, cabendo, então, às políticas governamentais de cunho liberal, oferecer respostas ante esse quadro de crise do mundo industrial taylorista-fordista.

Essas políticas repercutiram no Brasil no início da década de 1990 com a ascensão do governo Fernando Collor de Mello, o qual inicia um processo de abertura econômica que forçou à competitividade uma economia que fora desenvolvida sob a égide do protecionismo comercial. Aqui, é necessário elucidar que, antes de conduzir à reestruturação do parque siderúrgico, essa abertura econômica não preparou a indústria brasileira para a concorrência internacional que se seguiria (DRUCK, 1999, p.113). 
Segundo Cunha (2001, p.10) e Druck (1999, p.154), entre os fatores que colaboraram para pressionar as empresas em direção a uma estratégia inovadora destaca-se:

1. o aprofundamento da crise econômica da década de 1990, que reduziu o mercado interno, forçando as empresas a se voltarem para o exterior;

2. a política econômica colocada em prática pelo governo Collor - com um discurso liberal sobre a necessidade de as empresas melhorarem suas estratégias de produtividade e qualidade para enfrentar a concorrência internacional -, que estimulou as empresas nacionais a investirem na modernização tecnológica e na inovação das formas de organização e de gestão de mão-de-obra para garantirem sua permanência no mercado.

Como afirmam Cunha (2001, p.8) e Ferraz (2001, p.21), o setor siderúrgico deparava-se com sérios entraves ao seu desenvolvimento antes do processo de privatização:

- alto nível de endividamento;

- limitações de investimentos em pesquisa tecnológica;

- parque industrial desatualizado / parque industrial obsoleto;

- limitações comerciais;

- baixa autonomia de planejamento e estratégia;

- política de tabelamento e controle de preços;

- falta de competitividade das empresas do setor; e

- gestão burocratizada.

A privatização do parque siderúrgico brasileiro foi um fator determinante para o seu processo de reestruturação produtiva, no sentido de ampliar a capacidade do setor e, principalmente, de contribuir para a internacionalização da indústria, que se adequou ao estágio da siderurgia mundial. A privatização possibilitou o término de um longo período cujo enfoque principal fora o modelo de substituição de importações, pelo qual as empresas operavam em segmentos não concorrentes entre si. Isso gerava transtorno em termos de preços e qualidade para os consumidores, resultante da falta de competitividade. Também deve ser salientado que o setor passou a destinar uma maior parcela da produção ao mercado interno, a preços mais competitivos que os praticados nas exportações (CUNHA, 2001, p.10; SOARES, 2002, p.187).

O processo de privatização das empresas estatais foi um dos mais acelerados e abrangentes de que se tem notícia na história da economia do mundo. Os governos posteriores preservaram essa política de abertura externa e de privatizações; tanto que no governo Itamar Franco a abertura econômica foi intensificada, com a redução das tarifas de importação e a sobrevalorização do real, tendências essas mantidas no governo Fernando Henrique Cardoso (DINIZ, 1999, p.52).

As estatais privatizadas iniciaram a reestruturação produtiva calcadas nos seguintes parâmetros:

- modernização tecnológica;

- enobrecimento da linha de produtos;

- aumento de investimentos em controle ambiental;

- adoção de novos modelos de administração;

- autogeração de energia;

- desenvolvimento de usinas semi-integradas; e 
- intensificação do emprego de tecnologias poupadoras de mão-de-obra, como automação de base microeletrônica e processos de produção mais compactos (CUNHA, 2001, p.19; FERRAZ, 2001, p.22; OLIVEIRA, 2000, p.28).

Segundo esses autores, as principais conseqüências da privatização para o setor foram:

- aumento da concentração da produção e a centralização do capital;

- aumento da produtividade através da drástica redução do número de trabalhadores (ajustes pré e pósprivatização);

- maior agilidade administrativa;

- fim das restrições à diversificação de atividades;

- redução de despesas financeiras, em função do saneamento financeiro pré-privatização;

- acesso a fontes de financiamento novas e mais baratas;

- mudanças do regime de preços, com extinção dos mecanismos de controle formal, o que reduziu, por um longo período, os preços internos do aço; e

- autonomia para planejamento e estratégia de atuação.

- Quanto aos instrumentos de ajuste gerencial na siderurgia brasileira, deve-se pontuar:

- a modernização dos sistemas de programação tecnológica e de controle de produção;

- a reformulação dos processos de trabalho, no sentido de estimular a participação mais ativa e autônoma dos operários e instituir mecanismos de trabalho em equipe;

- os sistemas de garantia de qualidade, com a certificação pelas normas da International Organization for Standardization (ISO), ${ }^{3}$ com práticas inspiradas no Controle de Qualidade Total;

- a modificação de políticas de recursos humanos, com ampliação do esforço de treinamento e das exigências de qualificação do trabalhador;

- uma maior exigência de qualificação no processo de seleção;

- a implantação de esquemas de remuneração variável vinculada ao desempenho; e

- a supressão de níveis hierárquicos de comando e o repasse de atividades anteriormente desenvolvidas dentro das usinas para empresas especializadas ${ }^{4}$ (OLIVEIRA, 2000, p.30).

De acordo com a literatura, a reestruturação produtiva provocou um deslocamento do emprego do setor industrial para o setor de serviços no Brasil, fenômeno observado internacionalmente (ANTUNES, 2002, p.137; NEVES, 1998, p.334).

No que diz respeito aos impactos da reestruturação produtiva sobre a organização do trabalho, detecta-se um conjunto de transformações de caráter excludente e extremamente nocivo em termos sociais. Nesse sentido, Harrison (apud LEITE, 2003, p.67) denomina dark side da era da acumulação flexível, evidenciando desoladoras implicações sociais como: o aumento do desemprego, a precarização do trabalho, o rebaixamento salarial, a instabilidade no emprego e a expansão das chamadas formas atípicas da contratação, como o trabalho temporário e em tempo parcial.

No entanto, em conformidade com o cenário internacional, as implicações da reestruturação produtiva para o mercado de trabalho exprimem precariedades e regressão. A reestruturação produtiva trouxe como consequiência a fragmentação e a heterogeneidade da classe trabalhadora, redução de empregos no setor industrial, destruição de postos de trabalho, geração de bons e maus empregos e a diversificação crescente do setor de serviços. Além do mais, o trabalho é efêmero e instável e os dispensados têm dificuldades de conseguir emprego no mesmo setor industrial ou em outro ramo do segmento formal da economia (ANTUNES, 
2002:136; GUIMARÃES, 2003, p.181; LEITE, 2000, p.54; MACHADO DA SILVA, 2003, p.160; NEVES, 1998, p.334).

Na concepção de Guimarães (2003, p.194), o desemprego atinge desigualmente os indivíduos, segundo as características de raça, idade, imigrantes, conforme as categorias socioprofissionais, o grau de instrução e as relações de gênero. Isto é, o desemprego, além de involuntário, é seletivo e as oportunidades de emprego estão desigualmente distribuídas entre diferentes grupos sociais.

Nesse quadro de insegurança e incertezas no mundo do trabalho, as implicações da reestruturação produtiva provocam a disseminação da idéia de que o trabalhador deve adaptar-se às mudanças nos processos produtivos, adotando o seguinte perfil profissional:

- desempenho de múltiplas habilidades, necessárias a realização de várias tarefas;

- uso da criatividade e iniciativa para solução de problemas;

- capacidade para o trabalho em grupo que envolva gestão de processos e comunicação;

- capacidade analítica para identificar as causas dos problemas;

- responsabilidade e adesão aos projetos da empresa;

- nível elevado de escolaridade; e

- busca por (re)qualificação.

A adoção desse novo perfil profissional é vista por Antunes (1995, p.31), Neves, (1998, p.341) e por Leite (2003, p.98) como capaz de proporcionar instrumentos e competências imprescindíveis à empregabilidade. Nessa dimensão, surge o conceito de empregabilidade relacionado à capacidade da mão-de-obra manter-se empregada.

A seguir, discute-se como a intensificação da reestruturação produtiva causa impactos nas cidades e faz com que os stakeholders locais (re)definam o papel das mesmas, adotando novos conceitos e métodos de planejamento, alterando os processos de gestão urbana com o objetivo de promover o desenvolvimento.

\section{Impactos da reestruturação produtiva sobre as cidades ã luz da teoria do novo regionalismo}

O debate sobre o papel da cidade-região ${ }^{5}$ adquire destaque na literatura, em função das mudanças no cenário internacional. As transformações advindas do esgotamento do modelo industrial fordista, a globalização, a reestruturação produtiva e a fragilidade do Estado-nação, não apenas para regular e induzir o desenvolvimento obtido nas décadas anteriores, mas também para conduzir as clássicas políticas de gerenciamento macroeconômico (buscando pleno emprego, estabilidade de preços e políticas industriais) impactam o desenvolvimento das urbes. Diante da confluência desses fatores, as cidades passam a vivenciar processos de desindustrialização e de redução de níveis de emprego, além de transformações na estrutura socioespacial (COMPANS, 2001, p.120; RIBEIRO; SANTOS JÚNIOR, 2000, p.15; VELTZ, 2001, p.140).

Nessa perspectiva, Klink (2001, p.56) reporta que esse protagonismo da cidade no processo de reestruturação produtiva vem sendo analisado no âmbito do atual debate sobre a teoria do novo regionalismo. Essa teoria busca explicar as tendências de desenvolvimento local do ponto de vista das vertentes globalista e regionalista. A via globalista é baseada no triângulo de pressupostos que englobam homogeneização do espaço, mobilidade de fatores de produção e concorrência entre lugares. É importante salientar que essa vertente apresenta quatro variações.

A primeira variação da via globalista da teoria do novo regionalismo é inspirada nos processos de reestruturação produtiva, que no período de 1970 a 1980 tiveram impacto no nível de emprego industrial dos 
países capitalistas desenvolvidos, principalmente, nas cidades norte-americanas e européias. Para explicar esse fenômeno, surge a escola da nova política urbana, que busca analisar as questões de política de desenvolvimento local no âmbito internacional. A questão premente dessa escola é discutir a crise que se manifesta nas cidades industrializadas dos países desenvolvidos na década de 1970, associada ao fechamento de fábricas, ao surgimento de antigas áreas industriais degradadas, com galpões vazios, e ao crescimento da exclusão social e da pobreza urbana.

Vale ressaltar que, para essa escola, a única saída dos stakeholders locais é oferecer todos os tipos de concessões (isenções tributárias, redução de custos logísticos, doações de terrenos, empréstimos subsidiados, créditos e infra-estrutura urbana) e implementação de investimentos do próprio governo local para atrair atividade econômica. Essa corrente também enfatiza a necessidade de se realizar coalizações locais; isto é, de serem implementadas estratégias consensuais pelos stakeholders, objetivando definir a atratividade da malha urbana como espaço de competitividade, de retomada do crescimento e de garantia de conectividade com a economia mundial.

Explicar a reestruturação produtiva à luz da teoria do novo regionalismo, com suas duas vertentes, uma das quais defende a isenção fiscal, é uma escolha que decorre do fato dessa isenção ser uma saída advogada pelos stakeholders quanto ao objeto de estudo de caso aqui escolhido. Isto é, os stakeholders locais vão ao encontro dessa vertente que defende não só o simples incentivo fiscal, mas todo um conjunto de ações, como por exemplo, cooperação, parcerias, redução de conflitos entre os stakeholders locais etc. Não se trata aqui de defender esta ou aquela posição, a favor ou contra a isenção fiscal.

A segunda variação da via globalista da teoria do novo regionalismo surge no final dos anos 1980 e enfatiza a competição entre as urbes e as regiões européias no cenário de integração dos países ao mercado europeu. De um lado, a redução das barreiras comerciais entre as economias nacionais proporciona mobilidade de capital e de mão-de-obra no espaço - observando que a queda das barreiras aduaneiras amplia as potencialidades para que as regiões competitivas obtenham vantagens no comércio internacional -; de outro, os Estados nacionais estariam entregando a capacidade de elaborar e executar políticas macroeconômicas ao nível supranacional.

A unificação dos blocos econômicos e a abertura de mercados em nível global têm despertado rivalidade entre as cidades pela captação de investimentos, criação empregos e pela atração de financiamentos públicos e de turistas. Esse conjunto de fenômenos urbanos exige dos administradores e gestores urbanos uma reação ante a atuação de seus competidores.

Essa tendência representa ampliação dos novos instrumentos das políticas urbanas, como o city marketing, a produção da imagem e estratégias de concorrência entre as cidades européias. Ademais, esses instrumentos de políticas urbanas podem ser considerados como: 1- importante instrumento do chamado novo planejamento urbano, que busca estimular o processo de reestruturação urbana; 2- instrumentos para legitimar os interesses das coalizações dominantes no lugar.

A terceira variação da via globalista da teoria do novo regionalismo emerge na década de 1990, com o surgimento de redes de cidades e regiões que estariam conectadas entre si numa sociedade global baseada no novo ciclo de desenvolvimento, impulsionado pelas novas tecnologias das informações.

Os grandes avanços nas tecnologias de informação, telecomunicação e transporte podem ser transferidos com muita facilidade para qualquer lugar, on-line e sem custos transnacionais. Nesse aspecto, o estudo de Klink (2001, p.192) tem evidenciado três tendências que estariam ocorrendo: 1- as empresas transnacionais inserem várias unidades produtivas em territórios diferentes, gerenciando os fluxos de informações globais e maximizando os lucros da matriz em escala mundial; 2- a internalização da informática pelas operadoras financeiras proporciona aumento e rotatividade dos fluxos de capital financeiro; 3- a expansão do setor terciário subsidiado pelo avanço das telecomunicações. 
A quarta e última variação da vertente globalista da teoria do novo regionalismo anuncia o surgimento de uma ordem internacional sem fronteiras nacionais, com o esgotamento do papel do Estado-nação e de suas políticas de regulação macroeconômicas. Nessa perspectiva, Veltz (2001, p.148) compartilha com Borja e Castells (apud COMPÁNS, 2001, p.269) a análise de que o Estado perdeu grande parte das atribuições com a integração dos mercados, porque os fluxos econômicos ignoram a fronteira político-administrativa entre os países, colocando em xeque a própria idéia de economia nacional. As funções reguladoras que restariam aos Estados estariam sendo atingidas com a formação dos blocos econômicos e com a unificação de moedas. A perda do poder de regulação do Estado-nação, vinculado à crise fiscal e de legitimidade das instituições representativas tradicionais, assim como a descentralização administrativa, estaria propiciando o fortalecimento político e econômico dos governos locais, convertendo-os nos interlocutores dos investidores externos na busca por vantagens competitivas para as cidades.

Como considera Castells (1999, p.93), o Estado-nação torna-se menos operante no contexto da globalização e menos representativo em nível nacional. Nesse sentido, o Estado encontra uma estratégia para sobreviver à globalização com a formação de cartéis políticos de representação de interesses, nos quais há uma constante negociação com os agentes econômicos transnacionais, no sentido de gerenciar o impacto causado pelos fluxos globais de riqueza e informação sobre o país.

Discutindo vários desses aspectos, Klink (2001, p.97) e Sánchez (1999, p.126) ressaltam que, para viabilizar a conectividade e a inserção da região na concorrência global, torna-se necessário à cidade solucionar os seus conflitos que possam interferir no projeto de competitividade e conscientizar os atores sociais acerca do momento crítico pela qual passa a cidade-região. Após esse diagnóstico, compete à liderança local e regional criar um projeto consensual de revitalização econômica e social voltado para questões de emprego, habitação, qualidade de vida e marketing urbano. Através desses projetos simbólicos, a cidade-região pode apresentar para o capital (inter)nacional as mudanças que vêm ocorrendo.

A segunda vertente da teoria do novo regionalismo, denominada regionalista, enfatiza a importância da reterritorialização do desenvolvimento econômico no contexto da economia internacional globalizada. Este deve ser entendido como um processo que garanta condições econômicas, políticas, sociais e culturais concentradas num determinado local. Entretanto, o discurso dessa via destaca que a política pública deve criar, a partir das particularidades do próprio ambiente local, uma economia regional competitiva.

Essa vertente defende a existência de uma rede de relações interempresariais baseada em mixes de cooperação, competição, troca de informações e confiança. Essa vertente regionalista tem dentre seus pilares a participação dos stakeholders locais. Ou seja, a articulação conjunta dos stakeholders locais num ambiente de coesão social é precondição para o sucesso das cidades. Os casos paradigmáticos nesse sentido são a Terceira Itália e o Vale do Silício (na Califórnia), onde as empresas de pequeno e médio porte se baseiam nesses mixes de cooperação.

A segunda corrente da via regionalista da teoria do novo regionalismo é baseada nos pressupostos que englobam a escola francesa de regulação (EFR), o desenvolvimento endógeno e a formação de pólos regionais. A vertente regionalista apresenta três variações diferentes.

A primeira é representada pela EFR, que busca investigar e responder por que determinado modelo de desenvolvimento funciona bem em certos períodos e entra em colapso em outros. O resultado dessa indagação resulta de uma análise da transição do paradigma fordista que está se mesclando ou sendo substituído pelo regime de acumulação flexível. $\mathrm{O}$ fordismo impulsionou a emergência das metrópoles que reforçam seu poder de decisão e sua participação na economia mundial. Porém, a partir do decurso da década de 1970, o modelo fordista entrou em crise, como já foi discutido, e essas mudanças se traduzem em novas transformações no padrão de urbanização mundial.

O paradigma pós-fordista caracteriza-se pela flexibilidade, tanto no sentido tecnológico e organizacional como espacial. No que se refere à flexibilidade tecnológica, o sistema de produção é baseado na busca de nichos de 
mercado e de economia de escopo. Outra característica essencial desse modelo é a flexibilidade do mercado de trabalho com dualidade entre trabalho qualificado/não qualificado e freqüentes subcontratações.

Com relação ao sentido espacial, verifica-se que o processo de subcontratação entre os empreendimentos de pequeno e médio porte, baseado nas relações de troca de informações e de experiências, favorece uma localização aglomerada, para reduzir custos de transação e informação. Outro aspecto que deve ser enfatizado é que o modelo de acumulação flexível favorece a formação de clusters de pequenas e médias empresas no espaço.

Por último, o regime pós-fordista favorece a regulação local através de parcerias entre os governos locais, associação de empresas e outros stakeholders, o que é mais fácil de implementar nas aglomerações.

A segunda variação da vertente regionalista da teoria do novo regionalismo surge na década de 1980, com o interesse de economistas e geógrafos por questões de desenvolvimento regional endógeno. Para esse grupo, as economias de aglomeração são interpretadas como resultado direto da estratégia de minimização dos custos de transação e de monitoramento pelas empresas através da proximidade espacial.

A terceira variação da vertente regionalista da teoria do novo regionalismo desenvolve-se também na década de 1980 e concentra-se nas questões de alta tecnologia, de sistema de inovação e de pólos tecnológicos como pontos de partida para o desenvolvimento regional endógeno. Os exemplos nesse sentido são o Vale do Silício (Califórnia) e o Route 128 (Boston). O sucesso dessas duas áreas norte-americanas está relacionado a vários fatores que contribuem para uma ação coordenada entre empresários, à abundância de capital de risco, a uma malha urbana que proporciona alta qualidade de vida para a mão-de-obra que vive nesses distritos industriais, à interação entre empresas, à sociedade civil organizada, sindicatos de trabalhadores e governos locais. Esses fatores servem de base para uma negociação implementada a partir da própria região com a economia global.

O discurso da vertente regionalista, em geral, postula que o poder local é capaz de reterritorializar o desenvolvimento em um ambiente cultural de coesão social e comprometimento, fundamentado em redes interinstitucionais de confiança e cooperação, com a participação dos stakeholders locais. É importante assinalar que essas redes constituem precondição para o sucesso das cidades, no sentido de promover uma economia regional competitiva.

É necessário destacar que, através de negociações da construção de consensos e condescendência voluntária no interesse de cada parte, as cidades teriam o potencial de mobilizar os stakeholders locais para desenvolver bens e serviços.

A perspectiva regionalista apresenta uma inquietação com a criação de um mundo regional de produção pósfordista, evidenciando a necessidade de um sistema de relações regional mais cooperativo e menos fragmentado. A rede de cooperação, as relações de parceria e os acordos entre os diversos stakeholders locais são condições para se estabelecer uma governança que possibilite o sucesso das políticas públicas.

A construção da governança estimula a negociação e a construção de consensos em torno de ações específicas. Deve ser compreendida como execução de políticas públicas voltadas para a competitividade, com o objetivo de atrair investimentos perante o conjunto dos atores sociais presentes na cidade. De acordo com Borja e Castells (apud KLINK, 2001), a governança é criada por um conjunto de fatores:

1. inclusão através de programas sociais integrados, elemento essencial para garantir um aumento da produtividade urbana;

2. construção de parcerias público-privadas e parcerias privado-privadas que estimulem a implementação de estratégias consensuais de revitalização;

3. a cidade empreendedora deve estar preparada para assumir novas responsabilidades dentro do pacto federativo, ao considerar a fragilidade do Estado-nação; 
4. o poder aglutinador dos planos e projetos estratégicos combinados com a liderança do prefeito.

Para finalizar, a vertente regionalista enfatiza uma política pública que é elaborada a partir das particularidades do próprio ambiente local, que se define em termos de um conjunto de normas e convenções entre os atores regionais para coordenação da atividade econômica regional competitiva.

Cumpre lembrar, finalmente, que há um consenso entre as duas vertentes sobre o esgotamento do papel do Estado-nação em regular e induzir o desenvolvimento nacional e regional. Destacando esse aspecto, Borja e Castells (apud COMPANS, 2001, p.226) argumentam que as funções tradicionais e reguladoras que restariam ao Estado estão sendo reduzidas com a integração dos mercados, porque os fluxos econômicos ignoram suas fronteiras político-administrativas, reduzindo a sua soberania. Esse fato, aliado à descentralização administrativa, à crise fiscal e de legitimidade das instituições representativas estão propiciando um fortalecimento político e econômico dos governos locais municipais, em busca de vantagens no processo de competição econômica.

Ambas as tendências sublinham que o problema do desenvolvimento e a discussão sobre a territorialização do desenvolvimento se traduzem por questões de eficiência e de competitividade. Nesse sentido, os governos locais vêm mudando a sua abordagem, assumindo políticas antes reservadas ao Estado-nação, voltadas para o gerenciamento de serviços urbanos e para um estilo mais empreendedor.

Nesse panorama, o Brasil insere-se nessa discussão através de uma reflexão mais crítica e aprofundada a respeito do arcabouço da teoria do novo regionalismo e do novo papel das cidades. Um número crescente de cidades brasileiras assume novos compromissos na agenda de geração de emprego e renda, implementando políticas de atração de empresas e de atividades econômicas. A disseminação de um novo conceito e método de planejamento constitui objetivo a ser perseguido pelas cidades que pretendem inserir-se nos fluxos econômicos globais e locais (GUIMARÃES NETO; ARAÚJO, 2000, p.45; KLINK, 2001, p.61; RIBEIRO; SANTOS JÚNIOR, 2000, p.14; SÁNCHEZ, 2003, p.452).

Apesar de ter sido constatado por Diniz (2000, p.37) e por Piquet (1996, p.86) o declínio econômico das regiões industriais no Brasil, resultante do processo exacerbado de reestruturação produtiva e da emergência de novas áreas industriais ${ }^{6}$ no país, não se verificam mudanças na estrutura social, segundo o modelo de cidade pósindustrial.

Constata-se que, nesse contexto, a indústria permanece impulsionando o crescimento econômico nacional, mas, no que se refere à retomada de investimentos, a participação das cidades tem declinado em decorrência da desconcentração nas áreas metropolitanas - como, por exemplo, em São Paulo, no Rio de Janeiro e em Porto Alegre - e da criação de novos centros urbanos (DINIZ, 2000, p.28; PIQUET, 1996, p.73; RIBEIRO; SANTOS JÚNIOR, 2000, p.13). Apesar do avanço da reestruturação produtiva ter modificado as bases econômicas dessas áreas, estas continuam apresentando características de uma industrialização retardatária e interrompida (Mammarella, 2001, p.154; Piquet, 1996, p.82).

Neste momento em que o papel do Estado-nação encontra-se delibitado para formular políticas públicas, abrese espaço para a reforma urbana e para a disputa por investimentos produtivos entre os governos subnacionais (estadual e municipal), cada qual procurando usar suas próprias armas, proporcionando um quadro de crescentes rivalidades inter-regionais.

Essa disputa exarcebada, sem a presença (ou com a presença reduzida) do poder central, estimula a (re)valorização do papel do governo local como aquele capaz de dar respostas à crise de governabilidade e de legitimidade do Estado nacional. Nesse aspecto, as iniciativas locais têm que se mostrar surpreendentemente ágeis e capazes de realizar articulações com outros stakeholders locais pela captação de investimentos produtivos para a cidade, atributos que anteriormente eram reservados ao Estado-nação.

As pesquisas desenvolvidas por Compans (1999, p.126) e Sánchez (1999, p.120) apontam que as tendências das políticas promocionais da imagem das cidades consistem na valorização da dimensão local no circuito da 
globalização. A mobilidade produtiva e financeira permite maior liberdade de localização e também aumenta a importância das diferenças e dos atrativos locacionais. Através desse marco, os gestores urbanos vêm tomando consciência da permanente competição acirrada e predatória com as outras cidades por novos capitais.

É preciso salientar que, por detrás da competição entre as cidades, encontra-se a competição entre as empresas em busca de doações de espaços físicos, de isenção de tributos e de infra-estruturas física e comunicacional. Ao mesmo tempo em que as empresas buscam localizações vantajosas, que exigem segurança e rentabilidade para os capitais, os governos locais procuram manter as empresas existentes na cidade e também procuram novas empresas.

A busca por novos investimentos compromete várias urbes que são marcadas por diferenças socioespaciais. No entanto, Telles (2001, p.36) salienta que a modernização pode fragmentar o território entre ilhas de dinamismo e regiões excluídas dos circuitos de uma economia globalizada, o que redefine a cartografia da pobreza e amplia a crise social das cidades.

Nesse cenário de reestruturação urbana, o planejamento estratégico e o "marketing da cidade" vêm sendo apresentados, no caso brasileiro, como os melhores instrumentos, capazes de obter respostas para as novas situações provocadas pela globalização e pela reestruturação produtiva. A cidade passa a ser tratada como produto a ser vendido e o city marketing vem se convertendo numa das funções básicas do poder local. Através desse city marketing, a cidade deve construir uma imagem de espaço produtivo e seguro e de um clima favorável para se fazer negócios, com o objetivo de atrair capital (inter)nacional para criar novas bases para o desenvolvimento econômico local (COMPANS, 1999, p.92; SÁNCHEZ, 1999, p.131).

Portanto, essas novas city development strategies local que vêm sendo difundidas têm como pressuposto que a nova geografia do espaço financeiro e industrial redefine o papel das cidades como lugares de comando e de gestão sobre os fluxos de capitais, de mercadorias e de informações. Nesse sentido, o grande desafio do poder local consiste em buscar um novo conceito de desenvolvimento no qual estejam inseridos não apenas os interesses do capital, mas também as diferentes segmentações de trabalhadores.

Realizamos no próximo tópico uma breve reconstituição da história da Usiminas em Ipatinga, descrevendo como foi projetada a idéia da criação da empresa e como foi escolhido o local para sediá-la. A Usiminas assumiu funções do Estado, praticamente, construindo a cidade, nos moldes da grande empresa fordista. Essa relação de dependência econômica da cidade em relação à empresa ainda se mantém.

\section{O projeto de construção da Usiminas e da cidade de Ipatinga}

A cidade nasceu inspirada pela mentalidade nacional-desenvolvimentista da Federação das Indústrias de Minas Gerais (Fiemg), da Sociedade Mineira de Engenheiros, de intelectuais e do governo do estado de Minas Gerais, que defendiam a consolidação da indústria siderúrgica no estado, em razão de suas abundantes jazidas de minério de ferro (DAMIÃO, 1977, p.25).

Com Juscelino Kubistcheck na presidência da República e o lançamento do Plano Qüinqüenal de desenvolvimento econômico, Minas Gerais conseguiu realizar suas aspirações de obter uma usina siderúrgica. O projeto de construção da siderúrgica ocasionou uma série de conflitos entre as classes empresariais do Rio de Janeiro, de São Paulo e de Minas Gerais, cada qual interessada na dinamização de suas regiões (MONTEMÓR, 1997, p.364).

O Japão estava recuperando-se da derrota na II Guerra Mundial e buscava uma aproximação política com as nações do mundo ocidental através da demonstração de suas conquistas tecnológicas. O Brasil estava adotando uma política econômica propícia à participação de capital externo para os investimentos industriais e precisava de tecnologia estrangeira. 
Nesse cenário, foi consolidado o acordo nipo-brasileiro, estabelecendo uma joint venture em que o capital da empresa correspondia a $60 \%$ de participação do Brasil (40\% do governo federal e $20 \%$ do governo estadual) e $40 \%$ de participação do governo japonês. Nesse acordo, foram estabelecidos os pontos básicos de uma cooperação técnica entre as autoridades governamentais e grupos privados de ambos os países para a concretização do empreendimento.

De acordo com Damião (1977, p.50) e Frizzera (1990, p.155), a escolha do distrito onde instalar a empresa esteve condicionada a vários parâmetros adotados pela delegação japonesa:

1. facilidades de comunicação terrestre com grandes centros e zonas fornecedoras de minério de ferro e carvão mineral e de matérias-primas base para a produção do aço;

2. a usina deveria estar próxima a uma das maiores reservas de ferro, o Quadrilátero Ferrífero;

3. maior facilidade de escoamento da produção para o exterior, através do porto de Vitória no estado do Espírito Santo;

4. facilidade de obtenção dos recursos hídricos do rio Piracicaba, afluente do rio Doce;

5. facilidade de abastecimento de energia elétrica, feita inicialmente pela Usina Sá Carvalho e, posteriormente, pela Companhia Energética de Minas Gerais (Cemig);

6. proximidade de outros pólos industriais de Minas Gerais, como a então Companhia Siderúrgica Belgo-Mineira (CSBM, hoje Arcelor-Mittal), Companhia Vale do Rio Doce (CVRD) e a Acesita, situadas respectivamente em João Monlevade, Itabira e Timóteo (cidades mineiras da região conhecida como Vale do Aço);

7. pequena distância dos estados do Rio de Janeiro e São Paulo;

8. topografia apropriada e com possibilidade de expansão;

9. boa malha ferroviária e rodoviária.

O crescimento e o desenvolvimento econômico do distrito municipal que viria a se tornar a cidade de Ipatinga foram radicalmente alterados a partir de 1958, quando a usina siderúrgica começou a ser construída. Pode-se destacar como impactos mais gerais:

- a substituição da incipiente economia agrária de subsistência e de extração de carvão vegetal, atividade predominante na época, pela industrial e urbana;

- a intensificação de movimentos migratórios vindos de todas as regiões do Brasil e do Japão;

- o surgimento de um boom imobiliário e de caráter especulativo;

- a construção, às pressas, de uma cidade para abrigar a população trabalhadora;

- o crescimento de uma cidade espontânea, com favelização precoce (DAMIÃO, 1977, p.110).

Quando foram iniciadas as obras de construção da usina, o distrito era praticamente desabitado e desprovido de infra-estrutura capaz de suportar o intenso fluxo migratório que se seguiu - estimado em 10 mil pessoas a procura de trabalho -, motivado pela expectativa de uma vida melhor. Por isso, a Usiminas teve que, paralelamente, construir a cidade, para abrigar seus funcionários, os operários da construção civil e suas famílias, de forma que tivessem mínimas condições de vida, pois a região era semi-árida, inóspita, quase sem vegetação e isolada das aglomerações populacionais.

Desde então, a empresa construiu moradias (9.050 casas e 900 apartamentos), 220 edificações comerciais e institucionais (entre as quais: aeroporto, teatro, 28 escolas, um colégio secundário, cinco postos de saúde, um 
hospital, 20 clubes de lazer, cooperativas de consumo e hotéis), estação de tratamento de água e 19 templos religiosos, além de ter criado uma infra-estrutura de transporte e urbana (abrindo 50 quilômetros de sistemas viários vicinais e 11 quilômetros de ciclovias), sem contar a construção de um parque zoobotânico e os investimentos relacionados ao meio ambiente (FRIZZERA, 1990, p.128).

O estilo gerencial autoritário-paternalista da empresa, tipicamente fordista, caracterizou-a como o principal agente social na resolução dos problemas públicos e privados da cidade. Isso provocou dependência do poder local nas relações econômicas, culturais, políticas e comunitárias. A cidade foi concebida durante anos como extensão da atividade industrial, praticamente, não se estabelecendo distinção entre a administração da empresa e a da cidade.

Portanto, verificamos que as trajetórias históricas da empresa e da cidade se confundem. Constata-se que o sistema urbano e a população do Vale do Aço se constituem no entorno da Usiminas para atender às necessidades da empresa. Isso só se tornou uma preocupação para os stakeholders locais a partir da década de 1990, quando o país começou a discutir a privatização das estatais. No caso da Usiminas, temia-se que sua privatização provocasse profundas mudanças no mercado de trabalho, desencadeando transformações na economia local e alterações nos processos de gestão urbana.

A próxima seção discute como ocorreu o processo de privatização da Usiminas. Depois da privatização, a empresa passou a priorizar nova forma de gestão e de reorganização do trabalho, adotando modelos mais modernos e competitivos, que alteraram seu posicionamento no setor siderúrgico nacional.

\section{A privatização e a reestruturação produtiva da Usiminas}

A Usiminas foi escolhida a primeira empresa do Plano Nacional de Desestatização (PND) para iniciar o processo de privatização impulsionado pela política neoliberal do governo Collor. A empresa teve o mérito de sobreviver aos altos e baixos da política econômica das décadas de 1980 e 1990, enfrentando bruscas e excessivas oscilações nas condições econômicas, nos preços do aço e nas taxas de câmbio, além de preços internos tabelados pelo governo (SOARES, 2002, p.188). As recessões dessas décadas afetaram negativamente vários setores da economia brasileira, mas a empresa era considerada moderna, lucrativa e apresentava bons indicadores de eficiência empresarial se comparada com as antigas parceiras do grupo Siderbras. $\mathrm{O}$ depoimento a seguir ilustra a percepção de alguns dos gestores da prefeitura entrevistados: "durante todo o período dos anos 1980, o país passou por crises e, a despeito de todas as crises pelas quais a Usiminas passou, ela [se] modernizou e ao mesmo tempo foi criando uma estrutura na cidade [...]".

Segundo os entrevistados, a discussão sobre a privatização da usina foi tumultuada e marcada por posições radicalmente antagônicas na cidade. As manifestações e protestos antidesestatização reuniram o Partido dos Trabalhadores (PT), o Partido Comunista do Brasil (PC do B), o Partido Democrático Trabalhista (PDT), o Partido Comunista Brasileiro (PCB), o Partido do Movimento Democrático Brasileiro (PMDB), sindicalistas da Central Única dos Trabalhadores (CUT) e da Confederação Geral dos Trabalhadores (CGT), setores progressistas da Igreja Católica e a prefeitura de Ipatinga, então administrada pelo PT.

De acordo com depoimentos dos gestores da prefeitura e de empresários e sindicalistas entrevistados, esses atores sociais ensejavam algumas considerações relativas:

- à entrega do patrimônio nacional a grupos econômicos internacionais;

- à definição do valor de venda da empresa abaixo do mercado;

- às demissões em massa, provocando o agravamento dos problemas sociais;

- ao fato de que com a demissão dos trabalhadores, o município perderia renda devido à dependência econômica da cidade em relação à siderúrgica; e 
- à intensificação e sobrecarga de trabalho para os funcionários que não fossem demitidos.

Os grupos sociais defensores da privatização argumentavam que a venda da Usiminas e das outras estatais seriam benéficas para o país:

- pelo fato do Estado-empresário livrar-se dos setores que congestionavam e provocavam endividamento e a sua falência na tarefa de promover o crescimento econômico;

- pela oportunidade do Estado resgatar a dívida social e concentrar-se nas áreas de educação, saúde, segurança e previdência social;

- por aumentar a competição e a eficiência das empresas;

- pela permanente exigência de aportes de recursos para atualização tecnológica;

- por garantir autonomia gerencial para a adoção de decisões estratégicas ao desenvolvimento das áreas financeira, comercial e de recursos humanos da empresa.

De acordo com os dirigentes sindicais entrevistados, mesmo diante das resistências, o então diretor-presidente da Usiminas, Rinaldo Campos Soares, teve a missão de preparar, sensibilizar e debater com o público interno (empregados e aposentados) e com o público externo (sindicatos e outras associações de classes). Os sindicalistas ressaltaram o quanto a habilidade deste líder empresarial fora essencial para convencer a todos de que a implementação de uma nova etapa de desenvolvimento na empresa a livraria das amarras do Estadonação.

Entretanto, algumas considerações devem ser feitas sobre esse processo de convencimento que reverteu as expectativas negativas dos funcionários. Tanto sindicalistas, quanto empresários e gestores da prefeitura entrevistados salientaram que foi determinante possibilitar aos funcionários comprarem ações da empresa mediante políticas compensatórias do Banco Nacional de Desenvolvimento Econômico e Social (BNDES) - e o aumento de $5 \%$ nos salários que a própria empresa concedeu para custear essa compra. Assim, fomentou-se uma mentalidade privatizante que garantiu apoio e coesão social, como fica claro no seguinte depoimento de um dirigente sindical:

Nas assembléias com a categoria procurávamos detalhar com muita clareza todas as etapas do processo, repassando informações obtidas em reuniões com os responsáveis pelo programa de desestatização e com os diretores do BNDES.

A estratégia oposicionista de promover manifestações, em Ipatinga e na Bolsa de Valores do Rio de Janeiro, e de impetrar ações na Justiça para bloquear o leilão fracassou. A Usiminas foi privatizada em 24 de outubro de 1991.

Uma das estratégias da empresa pós-privatização foi diversificar a cadeia produtiva e também adquirir outras siderúrgicas, para melhorar sua posição como competidora (inter)nacional.

O sistema Usiminas é composto de empresas dos setores de siderurgia, de bens de capital e estamparia, de logística e de distribuição de serviços. O modelo de gestão do sistema prioriza a busca pela autogestão, o planejamento estratégico de longo prazo, o crescimento tecnologicamente sustentado e a diversificação dentro do seu foco de mercado.

Além de ampliar o sistema Usiminas, as principais mudanças que ocorreram na empresa foram nas áreas de estratégica, de compras, comercial, financeira e organizacional. Uma das preocupações levantadas nas entrevistas com os empresários, com os sindicalistas e com os gestores da prefeitura foi sobre a redução do número de funcionários. No gráfico 1, observa-se que essa redução ocorreu de forma gradativa: de 13.413 trabalhadores, em 1990, para 7.916, em 2002. No decurso daqueles anos, observa-se uma perda significativa de postos de trabalho: 5.497 empregos diretos. 
Gráfico 1

Número de trabalhadores da Usiminas

(1990-2002)

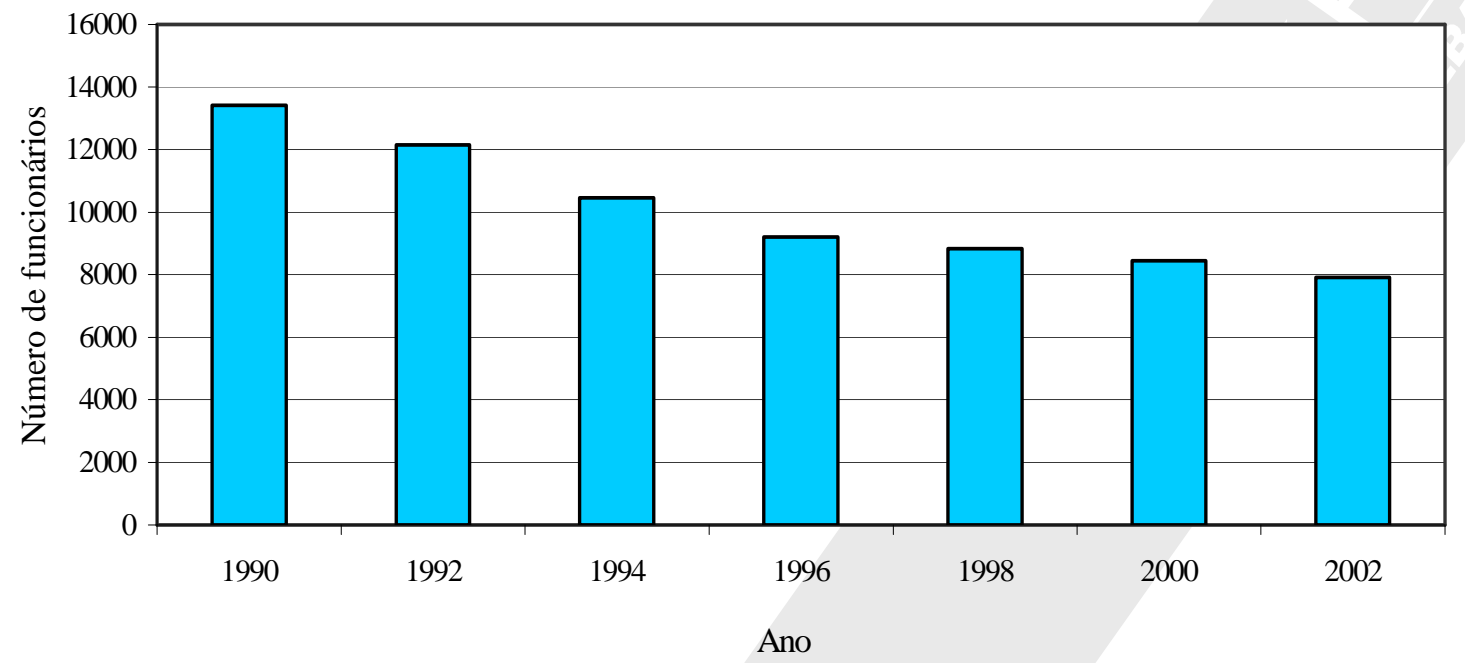

Fonte: Usiminas (2002).

Ademais, para forçar a redução de custos, a Usiminas vem intensificando a prática da terceirização, o que pode ser constatado na tabela 1 . O processo de terceirização destrói postos de trabalho nas "empresas-mãe", gerando a difusão de cadeias produtivas de pequenas e médias empresas subcontratadas, que assumem a produção de certos itens ou a prestação de determinados serviços, como, por exemplo, montagem, manutenção e inspeção de equipamentos, segurança, transporte de pessoal e de produtos, informática e o fornecimento de insumos e de suprimentos.

\section{Tabela 1}

Número de trabalhadores das empresas terceirizadas da Usiminas

\begin{tabular}{cc}
\hline ANO & TRABALHADORES \\
\hline 1991 & 4.263 \\
\hline 1992 & 3.779 \\
\hline 1993 & 4.081 \\
\hline 1994 & 4.297 \\
\hline 1995 & 4.795 \\
\hline 1996 & 4.515 \\
\hline 1997 & 5.320 \\
\hline 1998 & 5.378 \\
\hline 1999 & 5.242 \\
\hline 2000 & 5.458 \\
\hline 2001 & 5.469 \\
\hline 2002 & 5.059 \\
\hline 2003 & 5.238
\end{tabular}

Fonte: elaborada a partir de dados disponibilizados pela gerência-geral da Usiminas - 2004. 
Evidentemente, a redução de número de funcionários e as práticas de terceirização provocaram impactos sobre a economia ipatinguense, que tem na siderúrgica sua principal base de sustentação. Nesse sentido, podem ser destacados:

- a redução do volume de dinheiro fixo que circula no mercado decorrente do pagamento de salários, com reflexos no comércio, mesmo não sendo expressivo o número de falências de lojas ocorridas a partir de 1991; e

- o desenvolvimento do setor de prestação de serviços, com reflexos positivos na arrecadação do município através do Imposto Sobre Serviços de Qualquer Natureza (ISSQN).

Observando a dinâmica interna da economia ipatinguense no gráfico 2, verifica-se que está foi alterada de modo marcante ao longo do período analisado. Há tendência à diversificação intersetorial da economia urbana, com impulso considerável nas atividades terciárias. Os dados da Rais (Relação Anual de Informações Sociais) revelam clara tendência de transformação na composição do emprego formal, do setor industrial para o setor terciário (serviços, comércio e instituições financeiras) em expansão. 


\section{Gráfico 2}

Trabalhadores formais de Ipatinga por setor econômico

(1909-2002)

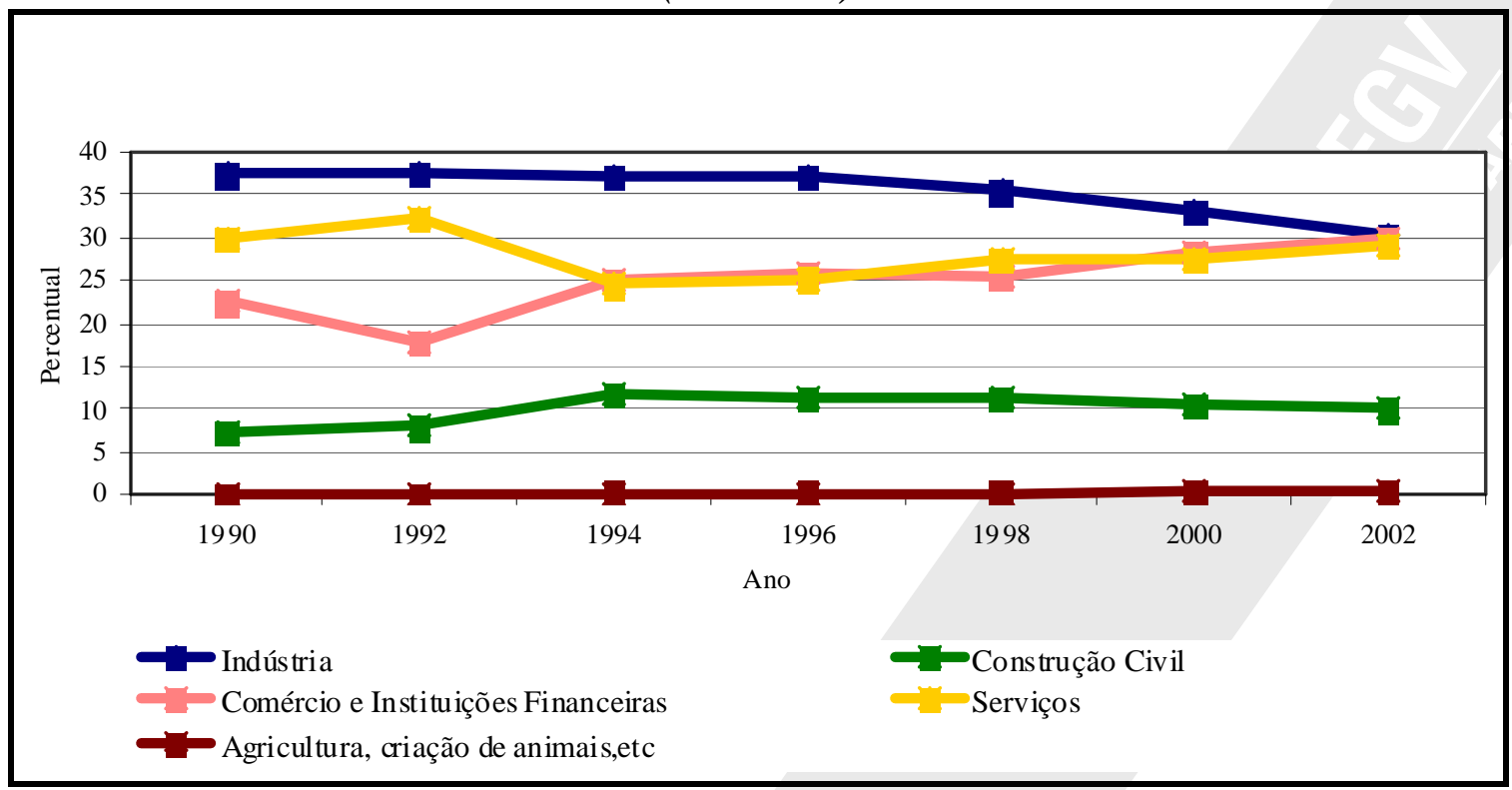

Fonte: Relação Anual de Informações Sociais (Rais) (1990-2002).

Essas mudanças na composição setorial do emprego estão relacionadas com o processo de privatização e a reestruturação produtiva da Usiminas, que representam à liberação de grande contingente de mão-de-obra e podem estar relacionados com dois aspectos a serem considerados:

- com a redução do quadro de funcionários da usina, os salários continuaram altos em virtude de aposentadorias antecipadas e de indenizações. Portanto, verifica-se mudança da atividade dos dispensados, seja por meio de um novo emprego no setor terciário ou por investirem na criação de atividades terciárias próprias, mantendo pequenos e médios negócios;

- o desenvolvimento do setor terciário é favorecido pelas obras de modernização e ampliação da empresa, com contratação de mão-de-obra temporária através das empresas terceirizadas.

A próxima seção explicita a preocupação dos empresários de Ipatinga com os impactos da reestruturação produtiva da Usiminas. Constata-se que a cidade está diante do desafio de desenvolver suas potencialidades numa perspectiva de competitividade, local e regional, pela atração de investimentos produtivos.

\section{Estratégias de desenvolvimento local dos stakeholders de Ipatinga}

Após a privatização em 1991, a Usiminas intensificou o processo de reestruturação produtiva. Em meio ao intenso processo de reformulação e de mudanças que aconteceu, a racionalização da mão-de-obra repercutiu na atividade econômica não apenas da cidade de Ipatinga, mas de toda a região do Vale do Aço.

Diante desse quadro, havia a preocupação por parte do empresariado local de que essas transformações pudessem ocasionar mudanças significativas no desenvolvimento do município, conforme já dito aqui, fortemente dependente da siderúrgica. Os empresários estavam ansiosos para se aproximarem do poder público local e apresentarem projetos para a dinamização da economia que gerassem novos empregos. 
Na primeira gestão do PT na prefeitura de Ipatinga, na administração Francisco Carlos Delfino (o "Chico Ferramenta")/João Magno, de 1989 a 1992, não havia essa aproximação entre os poderes público e privado. Os depoimentos a seguir ilustram a percepção de alguns gestores municipais e de empresários a esse respeito:

Era uma relação muito ruim porque havia aquela briga, era funcionário da empresa, candidatou para a diretoria do sindicato e foi demitido [prefeito Chico Ferramenta] da Usiminas. Ficou quatro anos na prefeitura, a Usiminas cumprindo com suas obrigações para pagar impostos, nunca deixou de investir, apesar de todo esse desencontro, esse confronto, que não foi só da prefeitura com a Usiminas, mas com o empresariado de modo geral [...].

O que nós da associação comercial poderíamos estar reivindicando junto ao poder público para fazer com que a cidade desenvolvesse? [Então,] nos aproximamos do prefeito e ele fez por bem encaminhar o projeto de criação desta secretaria [...].

Somente na segunda gestão do PT à frente da prefeitura de Ipatinga (1993-1996), na administração João Magno/Djalma Rodrigues, é que foi se formando uma consciência de participação dos stakeholders locais, com o objetivo de propor e consolidar novas alternativas de fomento ao desenvolvimento econômico local. Pelos depoimentos dos stakeholders locais, constata-se que, a partir de 1994, a PMI, a Associação Comercial, Industrial, Agropecuária e de Prestação de Serviços de Ipatinga (Aciapi), a Câmara dos Dirigentes Lojistas (CDL), o Sindicato Intermunicipal das Indústrias Metalúrgicas, Mecânicas e de Material Elétrico do Vale do Aço (Sindimiva) e a Usiminas estabeleceram cooperação para criar a Secretaria Municipal de Desenvolvimento Econômico (Semde).

A Semde surgiu no cenário pós-privatização com o propósito de promover o desenvolvimento e a diversificação econômica local, favorecendo a atração de novos investimentos produtivos e a instalação de novas empresas, visando, assim, reduzir a dependência econômica da urbe em relação à Usiminas.

A ação primordial da Semde para estimular o desenvolvimento local consiste em realizar parcerias para ativar e desenvolver os setores primário, secundário e terciário, fortalecendo o município como um dos pólos regionais mais relevantes do estado de Minas Gerais, assegurando a geração de emprego e renda.

Com propósito semelhante, também por iniciativa da Aciapi e da Usiminas, surgiu a idéia de estimular a criação da Agência de Desenvolvimento de Ipatinga (ADI), instituída no final de 1994. Para a consolidação da ADI, foram firmadas parcerias com a prefeitura, com o Serviço de Apoio às Micro e Pequenas Empresas de Minas Gerais (Sebrae-MG), com o Sindimiva e com a Câmara de Vereadores.

Os depoimentos de empresários e gestores da prefeitura indicam que a idéia de promover a criação da ADI surgiu basicamente de duas determinações: o primeiro propósito foi diversificar a base econômica do município, reduzindo sua excessiva dependência da Usiminas. Na opinião dos entrevistados, qualquer colapso que ocorrer na empresa pode provocar sérios transtornos para a cidade. Nesse sentido, argumentam que a própria empresa defende que o município procure diferenciar sua dinâmica econômica, com empreendimentos diferentes, pois os ipatinguenses valorizam o papel da Usiminas na geração de emprego e renda. A concepção dos empresários fica evidenciada nesta fala:

[...] o município de Ipatinga tem uma dependência em relação à Usiminas [Queremos] fazer um esforço para que essa dependência possa ser minimizada. Foi com esse espírito que a ADI foi criada.

Outro fator primordial que determinou a criação dessa agência foi a incumbência que recebeu para aproximar o poder público da Usiminas, já que a primeira gestão do PT não fora favorável a essa aproximação. Os trechos das entrevistas concedidos por um empresário e um gestor da prefeitura são claros nesse sentido:

[...] tanto a prefeitura, através da administração do João Magno, a Usiminas e os empresários, de uma maneira geral, entenderam que seria melhor para o município quebrar, digamos assim, as 
pequenas rixas, que de certo modo atrapalhavam o desenvolvimento da cidade. Isso contribuiu muito para que algumas ações pudessem ser levadas a cabo, e isso se traduziu em benefícios para a cidade.

[...] nós tivemos uma dificuldade na primeira administração do PT [...] perdemos e deixamos de caminhar e ganhar muito no nosso município.

O primeiro prefeito do PT tornou a ser eleito para os mandatos de 1997 a 2000 e de 2001 a 2004, estabelecendo como preceito a continuidade da aproximação entre o poder público municipal, a Usiminas e os empresários.

É consenso, entre todos os entrevistados da prefeitura, os dirigentes sindicais e os empresários que essa aproximação com o poder público tem sido contemplada, quando se faz uma analogia com a primeira gestão do PT na cidade, embora existam barreiras que não conseguiram romper. Ao analisar os depoimentos dos entrevistados, na perspectiva da teoria do novo regionalismo, verifica-se, no entanto, que a falta de cooperação, de confiança mútua e de coesão social entre os stakeholders locais - condição sine qua non para instituir governança - está dificultando a execução e os resultados as políticas públicas. Os depoimentos dos entrevistados deixam claro que é incipiente em Ipatinga esse ambiente de coesão e de confiança, como mostra o trecho da entrevista de um sindicalista:

[...] nos últimos anos essa relação tem melhorado [...], mas existe ainda uma barreira interna [...] que não conseguiram romper. Há muita briga, vaidade pessoal, de poderio econômico que atrapalha o desenvolvimento da cidade.

Os projetos desenvolvidos pela Semde e pela $\mathrm{ADI}^{7}$ não foram suficientes para estimular a economia e causar impacto significativo no nível de emprego e renda. Para os empresários e dirigentes sindicais entrevistados, o papel da Semde e da ADI deveria ser o de promover projetos de dimensões maiores. Os relatos de um gestor da prefeitura e de um sindicalista exemplificam essa análise:

"[...] várias coisas se tentaram fazer [...] implantação do distrito industrial, atividades junto ao governo do Estado, incubadora [...] nada disso, até hoje, foi bem sucedido para gerar desenvolvimento e absorver um número razoável de mão-de-obra".

"Gerar empreguinho [...] não depende de Agência de Desenvolvimento e da Semde. O papel desses dois órgãos é para projetos que têm envergadura. Isso só está na teoria. Não desenvolvem nada, apesar da boa vontade".

Na visão dos entrevistados, as expectativas quanto à criação de empregos e à geração de novos negócios em Ipatinga estão sendo frustradas, pois a prefeitura não oferece incentivo fiscal ou financiamento subsidiado para as empresas se instalarem no município, como discutido pela vertente globalista da teoria do novo regionalismo. Pela análise das entrevistas com sindicalistas e empresários, se o poder local não mudar de opinião sobre a cobrança de impostos, incentivos fiscais ou financiamento subsidiado, continuará o atual entrave para o desenvolvimento da cidade. Ilustrando essa afirmativa, seguem depoimentos de sindicalistas e empresários:

[...] participei de uma reunião para conversar sobre a vinda de uma indústria automobilística para a cidade [...], nós não tínhamos agentes políticos para conversar [...]. Qual foi a empresa que a prefeitura atraiu nestes últimos 16 anos para gerar emprego? [...] os agentes políticos não têm projeto de desenvolvimento para atrair indústrias, para usar a matéria-prima da Usiminas [...].

[...] desde que a secretaria foi criada, nada foi desenvolvido. Algumas empresas que manifestaram interesse para Ipatinga, não tiveram nenhum incentivo [...]. O poder municipal não incentiva nenhum empresariado a vir para cá. É um verdadeiro descaso da prefeitura com o desenvolvimento da cidade. Ipatinga nestes últimos 16 anos está florida, [...] mas sem emprego. 
Observa-se que a visão dos empresários e dos sindicalistas entrevistados é a mesma defendida pela vertente regionalista da teoria do novo regionalismo. Eles salientaram que parcerias com os atores sociais deveriam ser consolidadas, aproveitando-se o potencial da cidade, que é para a atividade siderúrgica, desenvolvendo assim a cadeira produtiva local. Essa discussão se baseia no fato de que a vocação do Vale do Aço é para o setor metalmecânico e de que a maioria dos suprimentos que a Usiminas e outras indústrias ali instaladas - como a Aços Especiais Itabira (Acesita) e a Celulose Nipo-Brasileira (Cenibra) - compram fora, poderia ser adquirida na própria região. $\mathrm{O}$ depoimento a seguir ilustra a percepção desses empresários sobre o problema:

Ipatinga sempre foi procurada pela grandiosidade da Usiminas [...]. A Usiminas é um atrativo para estimular a instalação de outras indústrias. Se a prefeitura tivesse o objetivo de atrair a cadeia produtiva da Usiminas, com certeza, a empresa privilegiaria política de compras dos fornecedores da cidade, gerando empregos e arrecadação para o município

Numa visão contrária à dos empresários e sindicalistas entrevistados, os gestores da prefeitura defendem a expansão do setor terciário, salientando que a vocação do município é a prestação de serviços e que o setor industrial não gera mais empregos quando se faz referência ao contexto atual.

Quanto a potencializar o desenvolvimento econômico da cidade com uma política industrial, de geração de emprego e renda, os gestores da prefeitura enfatizaram que compete aos agentes privados conduzir esse desenvolvimento e à prefeitura, apoiar.

Essa tendência dos gestores da prefeitura de Ipatinga se contrapõe à teoria do novo regionalismo, conforme citado por Klink (2001) e Harvey (apud Klink, 2001), no sentido de que os governos locais vêm mudando sua abordagem ao assumirem políticas antes reservadas ao Estado-nação, adotando uma postura mais empreendedora. Este depoimento de um dos gestores da prefeitura deixa claro que

[...] o poder público deve ficar cuidando da área da saúde e educação, por exemplo, do que se preocupar muito com a questão do crescimento e desenvolvimento da cidade [...].

Para os sindicalistas e os empresários entrevistados, os governos federal e estadual perderam a capacidade de conduzir políticas clássicas de gerenciamento macroeconômico, não sendo mais responsáveis por questões referentes a emprego e política industrial. Salientam que o poder público local tem que ser o carro-chefe na condução do desenvolvimento local, implantando políticas que antes eram atribuição exclusiva do Estado, pois estão mais próximos da realidade vivenciada pela população da cidade. Ilustrando essa afirmativa, um dirigente sindical ressalta que

Quem tem que gerar emprego são os agentes políticos [...]. Inclusive, se tivesse agente político mais atuante, frente à Usiminas, ela poderia estar ajudando a gerar mais emprego na cidade. Se Ipatinga estivesse há muitos anos com políticos com visão de futuro, nós não teríamos um número elevado de desemprego, porque eles deixaram para a Usiminas arrumar emprego para as pessoas. Isso não é papel da empresa e sim dos agentes políticos da cidade.

Na opinião dos gestores da prefeitura, de empresários e de sindicalistas entrevistados, desde a implantação da Usiminas, e mesmo após a emancipação de Ipatinga, a empresa tem realizado grandes investimentos na região. Pode-se notar que, após a privatização, a Usiminas manteve o compromisso de continuar investindo na cidade, embora tenha abandonado uma posição historicamente paternalista e assumido uma postura fundamentada na troca de ações sociais pela antecipação dos impostos.

Com o comportamento paternalista anterior à reestruturação produtiva, a empresa tornou-se o principal agente social na resolução dos problemas públicos e privados na cidade, o que provocou dependência de todos os segmentos sociais, dependência ainda não rompida, segundo os empresários e gestores da prefeitura entrevistados: 
Antes da privatização, a Usiminas construía tudo para a prefeitura. Hoje, não. Tudo o que a empresa constrói, troca por impostos.

[...] o maior impacto foi na área social, pois dependíamos da Usiminas para tudo [...]. Além dela pagar os impostos, investia muito na cidade. Agora, ela faz barganha, os impostos [...] se transformam em obras sociais.

Uma possível explicação para os gestores da prefeitura adotarem uma postura diferenciada da vertente regionalista da teoria do novo regionalismo - no sentido de não assumirem o compromisso de impulsionar a geração de emprego/renda e implementar políticas de atração de empresas e atividades econômicas para a cidade, via rede de stakeholders locais - pode ser a política paternalista adotada pela Usiminas quando era estatal. Uma vez abandonada essa postura assistencialista com a privatização, os gestores da prefeitura relatam que não existe, por parte da empresa, uma política voltada para promover o desenvolvimento local e regional:

[...] a Usiminas não tem uma política para induzir o desenvolvimento local. Não é função dela, e ela também não quer. [...] nenhuma das empresas da região como a Cenibra, a Usiminas e a Acesita, tem como interesse viabilizar parcerias para retomar crescimento.

[...] a Usiminas não é um agente ativo, impulsionador que fomenta o desenvolvimento da cidade, $e$ também não cria esse contexto.

\section{Considerações finais}

A reestruturação produtiva da Usiminas propiciou a rápida definição de expressivos programas de investimentos produtivos. Além do aumento no volume, os investimentos foram voltados para solucionar os principais problemas:

- modernização tecnológica (através da recuperação, substituição e instalação de novos equipamentos);

- enobrecimento de produtos (mediante ampliação e melhoria da qualidade das linhas de produção);

- reordenamento patrimonial atraindo novos players);

- diversificação da cadeia produtiva; e

- aquisição de outras siderúrgicas.

No caso específico da Usiminas, o ajuste foi menos traumático do que em outras siderúrgicas, devido a alguns fatores, entre eles:

- já vir ocorrendo na empresa uma redução no número de trabalhadores desde a segunda metade dos anos 1980;

- a realização de um plano de demissão voluntária;

- o remanejamento de trabalhadores para outras empresas do sistema Usiminas;

- a recolocação de trabalhadores dentro da empresa, exercendo outras funções;

- a transferência de trabalhadores para empresas terceirizadas;

- o fato de, nos acordos coletivos, a empresa ter se comprometido a não realizar demissões coletivas.

Ao enxugar suas estruturas organizacionais, a Usiminas passou a transferir parte dos serviços para empresas terceirizadas, e o número de trabalhadores das empresas terceirizadas aumentou. Evidentemente, essas mudanças decorrentes do processo de reestruturação produtiva repercutiram na atividade econômica do município, que é altamente dependente da empresa. 
Constata-se uma distensão no relacionamento da primeira administração petista com a Usiminas e os empresários. Partiu desses empresários a iniciativa de se aproximar do poder público local e fazer a intermediação entre a empresa e a prefeitura, visando estabelecer parcerias para fomentar o desenvolvimento econômico. Para incentivar esse desenvolvimento econômico, foram criadas a Semde e a ADI na segunda gestão do PT (1993-1996).

De acordo com os diferentes stakeholders locais entrevistados, apesar dessa aproximação entre poder público, empresários e Usiminas, as formas de cooperação permanecem limitadas. Houve pouco avanço na elaboração de mecanismos de cooperação; provavelmente, devido aos conflitos entre os stakeholders locais. Portanto, a rede de coesão social é praticamente inexistente, o que dificulta uma participação conjunta entre esses stakeholders no processo de tomada de decisão e, também, a criação de novas bases para o desenvolvimento econômico local.

Diante das dificuldades de se estabelecer uma cooperação, são desenvolvidos projetos pouco ousados que, na opinião dos stakeholders locais, são insuficientes para promover o desenvolvimento econômico. Na visão dos entrevistados, a prefeitura não oferece nenhum tipo de concessão em termos de incentivo fiscal, de investimentos diretos do próprio governo local ou de financiamento subsidiado para atrair empresas, o que dificulta o crescimento e o desenvolvimento econômico da cidade.

Em um ambiente no qual não há confiança nem tradição de comunicação entre os stakeholders locais, a conversação, segundo a teoria do novo regionalismo discutida por Klink (2001, p.60) serve para reduzir barreiras e, principalmente, para iniciar um processo de entendimento da posição do outro. No entanto, deverse-ia elaborar mecanismos de resolução dos conflitos no nível do poder local - isto é, sistematizando o mapeamento das posições e aspirações de cada um dos stakeholders envolvidos - e incorrer em estratégias que reconheçam os interesses de cada um. Para a vertente globalista, a viabilização desse consenso entre os stakeholders locais ocorre somente através de um projeto comum e de um sentimento de pertencimento à cidade, que ainda se mostrou incipiente em Ipatinga.

Os dados empíricos mostram que Ipatinga está caminhando para a vertente regionalista da teoria do novo regionalismo. Portanto, é preocupante o processo de relativo afastamento e distanciamento do incipiente sistema de governança implementado pelo poder local. Não obstante, o papel da Semde e da ADI leva a crer que serão articuladores e executores de políticas de desenvolvimento econômico e instituições-chave para intermediar a transição de um novo conceito de gestão urbana voltado para o empreendedorismo.

Observa-se que a sociedade local permanece atrelada ao mito fordista da grande empresa que emprega mão-deobra abundante, enquanto a tendência da empresa não consiste em expansão física em Ipatinga, mas sim na implantação de subsidiárias localizadas próximo a seus clientes em outras regiões. Assim, mesmo que haja constante modernização e aumento de produtividade na usina, a tendência é a retração ou a manutenção dos postos de trabalho no futuro. 


\section{Referências}

ANTUNES, Ricardo. As metamorfoses no mundo do trabalho. In: ADEUS ao trabalho? São Paulo: Cortez, 1995. p.13-39.

Sentidos do trabalho: ensaio sobre a afirmação e a negação do trabalho. São Paulo: Boitempo, 2002. 258 p.

CASTELLS, Manuel. Para o Estado-rede: globalização econômica e instituições políticas na era da informação. In: PEREIRA, L. C. Bresser et alii (Org.). Sociedade e Estado em transformação. São Paulo: Editora Unesp, 1999. p.147-171.

COMPANS, Rose.O paradigma das global cities nas estratégias de desenvolvimento local. Revista Brasileira de Estudos Urbanos e Regionais, Rio de Janeiro, n.1, p.91-114, 1999.

COMPANS, Rose. Cidades sustentáveis, cidades globais: antagonismo ou complementaridade. In: ASCELRAD, Henry (Org.). A duração das cidades. Rio de Janeiro, DP\&A, 2001. p.105-137.

CUNHA, José Mauro Mettrau C. da. Impactos do setor siderúrgico. 2001. 12p. Datilografado.

DAMIÃO, Everaldo. Terra e gente de Ipatinga. Ipatinga: Comunicação, 1977. 145 p.

DINIZ, Clélio Campolina. Impactos territoriais da abertura externa, privatizações e reestruturação produtiva no Brasil. In: SEMINÁRIO INTERNACIONAL DE LA RII, 5., Toluca, México, 21-24 de setembro de 1999. 22p.

. Impactos territoriais da reestruturação produtiva. In: RIBEIRO, Luiz C. de Q. (Org.). 0 futuro das metrópoles: desigualdades e governabilidade. Rio de Janeiro, Revan, 2000. p.21-61.

DRUCK, Maria da Graça. O modelo japonês nos anos 90 no Brasil. In: TERCEIRIZAÇÃO: (des)fordizando a fábrica. São Paulo: Boitempo, 1999. p.101-156.

FERRAZ, Alexandre Sampaio. Sindicatos e privatização no Brasil: um estudo do setor siderúrgico. In: ENCONTRO DA ABET, 7., Salvador, 21 a 26 de outubro de 2001. 25p.

FERREIRA, Cândido G. Crise do fordismo e novos paradigmas da organização da produção. Belo Horizonte: Departamento de Ciências Econômicas da UFMG, 1993. Datilografado. 15p.

FRIZZERA, Jussara. Usiminas conta sua história. Belo Horizonte: Fundação João Pinheiro, 1990. 182 p.

GUIMARÃES, Nadya A. Por uma sociologia do desemprego: contextos societais, construções normativas e experiências subjetivas. In: SANTANA, Marco Aurélio; RAMALHO, José Ricardo. Além da fábrica. São Paulo: Boitempo, 2003. p.179212.

GUIMARÃES NETO, Leonardo; ARAÚJO, Tânia Bacelar. Poder local, governos municipais e políticas de indução do desenvolvimento econômico no Brasil. In: SOARES, J. A. et alii (Org.). Os desafios da gestão municipal democrática. São Paulo: Cortez, 2000. p.9-60.

KLINK, Jeroen Johannes. A cidade-região: regionalismo e reestruturação produtiva no grande ABC paulista. Rio de Janeiro: DP\&A, 2001. 225p.

LEITE, Márcia de Paula. Qualificação, desemprego e empregabilidade. Revista da Fundação Seade, São Paulo, n.11, v.11, 2000.

A experiência brasileira da reestruturação e suas implicações sociais. In: Trabalho e sociedade em transformação: mudanças produtivas mudanças produtivas e atores sociais. São Paulo: Fundação Perseu Abramo, 2003. p.63-114.

MACHADO DA SILVA, Luís Antônio (2003). Mercado de trabalho, ontem e hoje: informalidade e empregabilidade com categorias de entendimento. In: SANTANA, Marco Aurélio; RAMALHO, José Ricardo. Além da fábrica. São Paulo: Boitempo, 2003. p.140-178. 
MAMMARELLA, Roseta et alii.Economia e ocupação no espaço metropolitano: Transformações recentes de Porto Alegre. BÓGUS, Lúcia; RIBEIRO, Luiz C. de Q. (Org.). Cadernos Metrópole, São Paulo, n.6, p.151-176, 2001.

MONTE-MÓR, Roberto L. de M. et alii. Ocupação do território e estrutura urbana. In: PAULA, João Antônio de (Coord.). Biodiversidade, população e economia. Belo Horizonte: UFMG, 1997. p.91-154.

NEVES, Magda de Almeida. Reestruturação produtiva e estratégias no mundo do trabalho: as conseqüências para os trabalhadores. In: CARVALHO NETO, Antônio M. de; CARVALHO, Ricardo A. (Org.). Sindicalismo e negociação coletiva nos anos 90. Belo Horizonte: IRT-PUC Minas, 1998. p.329-338.

OLIVEIRA, Vanessa Criscuolo P. de (2000). Privatizações, emprego e negociações coletivas na siderurgia mineira na década de 90: estudos de caso em duas siderúrgicas desestatizadas. Belo Horizonte, 2000. 31p. Datilografado.

PIQUET, Rosélia. Metrópoles e reestruturação produtiva no Brasil. Cadernos Ippur, Rio de Janeiro, v.10, n.2, p.77-87, 1996.

RIBEIRO, Luiz César de Queiroz; SANTOS JÚNIOR, Orlando Alves dos. O futuro das cidades brasileiras na crise. In: RIBEIRO, Luiz César de Queiroz; SANTOS JÚNIOR Orlando Alves dos (Org.). Globalização, fragmentação reforma urbana. Rio de Janeiro: Civilização Brasileira, 2000. p.11-19.

SÁNCHEZ, Fernanda. Políticas urbanas em renovação: uma leitura crítica dos modelos emergentes. Revista Brasileira de Estudos Urbanos e Regionais, São Paulo, n.1, p.115-132, 1999.

A reinvenção das cidades para o mercado mundial. Santa Catarina: Argos, 2003. 588 p.

SOARES, Rinaldo Campos. Siderurgia nacional: desempenho e desenvolvimento. In: EMPRESARIEDADE \& ética: o exercício da cidadania corporativa. São Paulo: Atlas, 2002. p.183-229.

TELLES, Vera da Silva. A cidade e o trabalho. Cadernos Le Monde Diplomatique, São Paulo, n.2, p.34-37, 2001.

USIMINAS. Relatório Anual. [S.I.], 2002.

VELTZ, Pierre. Tempos da economia, tempos da cidade: as dinâmicas. In: ASCELRAD, Henri. (Org.). A duração das cidades: sustentabilidade e risco nas políticas urbanas. Rio Janeiro: DP\&A, 2001. p.139-154.

\footnotetext{
${ }^{1}$ Entendidos como atores sociais, constituídos pelo poder público estadual e municipal, empresários, sindicatos, organizações nãogovernamentais (ongs) e outros setores da sociedade civil organizada, entre outras instituições responsáveis pelo desenvolvimento local e regional.

${ }^{2}$ Segundo Ribeiro e Santos Júnior (2000), os princípios de governança compreendem: 1- a identificação dos interesses e das forças sociais locais existentes na cidade; 2 - a construção de um pacto territorial que engloba três aspectos: a) a inserção da economia local no novo modelo de desenvolvimento gerado pela reestruturação produtiva e pela globalização das economias nacionais e regionais; b) a garantia dos direitos urbanos que assegurem um padrão mínimo de qualidade de vida definido pelas condições habitacionais, urbanas e ambientais; c) a reforma da máquina administrativa local visando dotá-la das condições de eficiência e eficácia necessárias ao poder público na governança do município.

3 É uma organização não governamental, fundada em 1947, com sede em Genebra, na Suíça. Tem como objetivo promover o desenvolvimento da normalização e atividades relacionadas, com a intenção de facilitar o intercâmbio internacional de bens e serviços, baseado na emissão de certificados de qualidade.

${ }^{4}$ Entre as atividades que eram realizadas pelas siderúrgicas e que foram repassadas para as empresas terceirizadas destacam-se: limpeza, embalagens, fabricação de gases industriais e distribuição de energia, entre outras.

${ }^{5}$ De acordo com Klink (2001), são áreas metropolitanas com mais de 1 milhão de habitantes e que estão inseridas nos processos globais de transformação socioeconômica, em que o poder local assume o compromisso de gerar emprego e renda, buscando atrair capital produtivo.

${ }^{6}$ De acordo com Diniz (2000), essas áreas industriais compreendem as regiões de Campinas, São Carlos e São José dos Campos no estado de São Paulo; Belo Horizonte, Pouso Alegre e Santa Rita de Sapucaí em Minas Gerais; Curitiba, no estado do Paraná; Florianópolis, em Santa Catarina; e Caxias do Sul e Porto Alegre, no Rio Grande do Sul.

Os projetos viabilizados pela Semde e pela ADI a partir de 1994 são: o Banco Popular, a Feira de Artes e Artesanato (Feirarte), o Conselho e Fundo Municipal de Turismo, a Associação dos Apicultores do Vale do Aço (Aapivale), a Cooperativa de Doces, a Usina de Leite, o Shopping Center e o Distrito Industrial.
} 